\title{
Türkiye'de Psikolojik Danışma ve Rehberlik Alanındaki Tezlerde Problemli Teknoloji Kullanımı
}

DOI: 10.26466/opus.906742

\author{
* \\ Önder Baltac1 * - Ömer Faruk Akbulut** \\ * Dr. Öğr. Üyesi, Ahi Evran Üniversitesi, Kırşehir/Türkiye \\ E-Posta: obaltaci@ahievran.edu.tr \\ ORCID: $\quad$ 0000-0002-9974-8507 \\ ** Lisansüstü Öğrencisi, Necmettin Erbakan Üniversitesi, Konya/Türkiye \\ E-Posta: omerfaruk2540@gmail.com \\ ORCID: $\quad$ 0000-0001-5152-8102
}

\section{Öz}

Bu araştırmanın amacı, Türkiye'de psikolojik danışma ve rehberlik alanındaki problemli teknoloji kullanımı ile ilgili yapılmış lisansüstü tezleri inceleyerek alandaki araştırma eğilimlerinin belirlenmesidir. Bu kapsamda araştırmada, problemli teknoloji kullanımı ile ilgili lisansüstü tezler belirlenen çeşitli ölçütler çerçevesinde incelendiği için içerik analizi yöntemi kullanılmıştır. Araştırma kapsamında YÖK Tez veri tabanında toplam 679 lisansüstü teze ulaşılmış ve bunlar arasından dahil edilme kriterleri göz önünde bulundurularak 105 yüksek lisans tezi ve 10 doktora tezi olmak üzere toplamda 115 lisansüstü tezi araştırma kapsamında incelenmek üzere seçilmiştir. Araştırma kapsamındaki lisansüstü tezlerin incelenmesi sürecinde araştırmacılar tarafindan hazırlanan "Araştırma Değerlendirme Formu" kullanılmıştır. Araştırma kapsamında incelenecek lisansüstü tezler dahil edilme kriterleri göz önünde bulundurularak belirlendikten sonra içerik analizine tabi tutulmuştur. Lisansüstü tezler; yayınlanma yıll, tez türü, üniversite türü, araştırma modeli, çalışma grubu, çalışma grubu büyüklü̈̆̈̈̈, kullanılan ölçme aracı, yapılan istatistiksel analizler, problemli teknoloji kullanımı değişkeni ve problemli teknoloji kullanımı değişkeni ile çalışılan diğer değişkenler ölçütleri çerçevesinde incelenmiştir. Araştırmanın sonuçları, alanyazın ışı̆̆ında tartışılmış ve önerilerde bulunulmuştur.

Anahtar Kelimeler: problemli teknoloji kullanımı, psikolojik danışma ve rehberlik, problemli internet kullanimi. 
Cilt Volume: 18

\title{
Problematic Technology Use in Theses in Psychological Counseling and Guidance in Turkey
}

*

\begin{abstract}
The aim of this research is to determine the research trends by examining the graduate theses about the problematic technology use in the field of psychological counseling and guidance in Turkey. In this context; since graduate theses on problematic technology use were examined within the framework of various criteria, content analysis method was used in the research. Within the scope of the research, a total of 679 graduate theses were reached in the YÖK Thesis database, and considering the inclusion criteria, a total of 115 graduate theses, including 105 master's theses and 10 doctoral dissertations, were selected to be examined within the scope of the research. During the examination of the graduate theses within the scope of the research, the "Research Evaluation Form" prepared by the researchers was used. The graduate theses to be examined within the scope of the research were subjected to content analysis after they were determined by considering the inclusion criteria. Graduate theses were analyzed within the framework of these criteria: the year of publication, thesis type, university type, research model, study group, study group size, assessment instrument used, statistical analysis, problematic technology use variable and other variables studied with them. The results of the research were discussed in the light of the literature and suggestions were made.
\end{abstract}

Key Words: problematic technology use, psychological counseling and guidance, problematic internet use. 


\section{Giriş}

Günümüzde birçok gelişme ve yenilik ile birlikte teknoloji, yaşamımızın tüm alanını çevreleyen bir araç olarak karşımıza çıkmaktadır. We Are Social (2020) tarafından yayınlanan "Dijital 2020" adlı raporda; Dünya nüfusunun \%67'isinin telefona sahip olduğu, \%59'unun internet kullanıcısı olduğu ve \%49'unun aktif sosyal medya kullanıcısı olduğu görülmüştür. Bireyler günlük yaşamlarında mesleki ve akademik sorumluluklarını, ev içerisindeki birçok sorumluluğu ve sosyal yaşamlarındaki aktiviteleri teknolojik araçlar üzerinden gerçekleştirebilmektedir. Teknolojinin bireyler üzerinde yarattığ 1 bu kolaylık bir fırsat olarak görülebilmektedir (Ögel, 2014). Ancak teknolojinin kontrolsüz, bilinçsiz ve sorunlu bir şekilde kullanımı sonucunda bireylerin yaşamları bu durumdan olumsuz olarak etkilenebilmektedir (Spada, 2014). Bireylerin teknolojiyi bu şekilde kullanması alanyazında "problemli teknoloji kullanımı" olarak ele alınmaktadır.

Problemli teknoloji kullanımı kavramı alanyazında problemli internet kullanımı, oyun bağımlılı̆̆ı, problemli akıllı telefon kullanımı ve internet bağımlılı̆̆ı gibi kavramları kapsayan genel bir kavramdır. Bu bağlamda problemli teknoloji kullanımı; bireylerin teknoloji kullanımlarını kontrol etmekte zorluk yaşamaları, teknolojiye ulaşamadıklarında zihinlerinin sürekli olarak teknoloji ile meşgul olması, teknoloji kullanımlarının günlük yaşam içerisinde aşırı bir zaman kaplaması ve bu durumların bireyin günlük yaşamını olumsuz etkilemesi olarak tanımlanabilmektedir (Block, 2008; Şata ve Karip, 2017; Young, 2011). Problemli teknoloji kullanımı kavramı; problemli internet kullanımı, internet bağımlılı̆̆ı, akıllı telefon bağımlılığı, çevrimiçi oyun bağımlılığı, sosyal medya bağımlılığı, nomofobi (akıllı telefonsuz kalma korkusu), çevrimiçi alışveriş bağımlılığı, çevrimiçi kumar bağımlılığı, siber zorbalık ve çevrimiçi pornografi bağımlılığı gibi kavramları içerisine alan bir çatı kavramdır (Savcı, Ercengiz ve Aysan, 2019). Bu kavramlar ilgili teknolojik aracın problemli, sorunlu ve kontrolsüz bir şekilde kullanımını ifade etmektedir. Örneğin; akıllı telefon bağımlılığı bireylerin akıllı telefonu aşırı, kontrolsüz ve yaşamlarına zarar verebilecek şekilde kullanımını ifade ederken çevrimiçi oyun bağımlılı̆̆ bireylerin çevrimiçi oyunları yaşamlarına zarar verebilecek düzeyde oynamaları olarak ele alınabilmektedir (Savc1, Ercengiz 
ve Aysan, 2019). Bu kavramlar arasından nomofobi, bireylerin akıllı telefonlarından uzak kaldıkları zaman yaşadıkları korku durumunu ifade eden bir kavram olarak tanımlanabilmektedir (Yildirim ve Correia, 2015). Bir başka problemli teknoloji kullanımı kavramı olan siber zorbalık ise bilgi ve iletişim teknoloji araçları kullanarak bir kişiye veya gruba yönelik şiddet davranışları olarak tanımlanabilmektedir (Erdur-Baker ve Kavşut, 2007). Günümüzde teknolojik araçların hızlı bir şekilde gelişmesiyle birlikte problemli teknoloji kullanımı durumu genç kesim başta olmak üzere bütün yaş gruplarını olumsuz olarak etkileyen yaygın bir sorun haline gelmiştir (Aboujaoude, 2010).

Problemli internet kullanımı özelinde problemli teknoloji kullanımının yaygınlığını belirlemeye yönelik 70 araştırmayı ve 122.425 üniversite öğrencisini içerisine alan bir meta-analiz çalışmasında, problemli internet kullanımının yaygınlığı \%11.3 olarak bulunmuştur (Li vd., 2018). Sert ve arkadaşları (2019) tarafından internet bağımlılığı özelinde problemli teknoloji kullanımının yaygınlığına yönelik Türkiye' de yapılan bir araştırmada ise internet bağımlılığının yaygınlığı \%10.5 olarak bulunmuştur. Kore'de akıllı telefon bağımlılığı temelinde problemli teknoloji kullanımının yaygınlığ 1 üzerinde yapılan bir araştırmada ise akıllı telefon bağımlılığı riskinin yaygınlığı \%35.6 olarak bulunmuştur (Lee ve Lee, 2017). Çevrimiçi oyun bağımlılığı açısından problemli teknoloji kullanımının yaygınlığını belirlemeye yönelik başka bir araştırmada ise çevrimiçi oyun bağımlılığının yaygınlığ $\% 12.6$ olarak bulunmuştur (Wittek vd., 2016). Problemli teknoloji kullanımının yaygınlığını belirlemeye yönelik bu araştırmalar genel olarak incelendiğinde, problemli teknoloji kullanımının günümüz teknoloji çağında evrensel bir sorun olarak ele alınabileceği görülmektedir.

Problemli teknoloji kullanımı, bireylerin fiziksel, psikolojik ve sosyal yaşamlarında olumsuz etkiler oluşturabilmektedir (Avşaroğlu ve Akbulut, 2020; Türkiye Yeşilay Cemiyeti, 2017). Türkiye'de lise ve üniversite öğrencileri ile yapılan "Teknoloji Kullanımı ve Bağımlılığı Açısından Türkiye Gençliğinin Fotoğrafı" adlı projede, problemli teknoloji kullanımının öğrencilerin aile, akademik ve sosyal yaşamlarında olumsuz etkiler oluşturduğu görülmüştür. Araştırmada, öğrencilerin teknoloji bağımlılı̆̆ı düzeyi arttıkça akademik başarılarının düştüğü, mutluluk ve yaşam doyumu düzeylerinin azaldığı görülmüşsür. Ayrıca araştırmada 
sağlıklı aile yapısının öğrencilerin problemli teknoloji kullanımı sorunu yaşamaları karşısında koruyucu bir role sahip olduğu görülmüştür (Sakarya Üniversitesi, İHH ve AID, 2015). Problemli teknoloji kullanımının bireylerin fiziksel yaşamları üzerinde etkisini inceleyen araştırmalarda ise bireylerin uyku kaliteleri, fiziksel ağrıları, beslenme alışkanlıkları ve fiziksel aktivitelerinin bu sorundan önemli oranda etkilendiği görülmüştür (Baranowski vd., 2011; Wang vd., 2020; Zheng, Wei, Li, Zhu ve Ning, 2016). Alanyazında yer alan bu araştırma sonuçları, problemli teknoloji kullanımının bireylerin fiziksel, psikolojik ve sosyal yaşamları üzerinde olumsuz etkiler oluşturduğunu göstermektedir.

Psikolojik danışma ve rehberlik hizmetleri; bireylerin kendilerini tanımaları, kabul etmeleri ve geliştirmeleri sürecinde gerekli yeterlikleri kazanmaları ve yaşam donanımlarına sahip olmaları için profesyonel kişiler tarafından sunulan psikolojik destek olarak tanımlanabilmektedir (Yeşilyaprak, 2020). Psikolojik danışma ve rehberlik hizmetleri sahip olduğu önleyici ve koruyucu işlevleri ile bireylerin ruh sağlı̆ıın belirleyen faktörleri etkilemeye ve kontrol etmeye odaklanmaktadır. Bu işlevler çerçevesinde bireylerin yaşamlarında psiko-sosyal sorunlar ile karşılaşmadan önce gerekli yaşamsal becerilere sahip olması ve pozitif ruh sağlığı oluşturarak yaşamlarında bu sorunlar ile karşılaştıklarında etkili bir şekilde başa çıkabilmelerini sağlamak amaçlanmaktadır (Savi Çakar, 2018). Problemli teknoloji kullanımının son yıllarda sıklıkla yaşanan bir sorun haline gelmesi ve bireylerin psiko-sosyal yaşamlarında olumsuz etkiler oluşturması psikolojik danışmanların bu konu üzerinde yoğunlaşmalarına neden olmuştur. Özellikle son yıllarda başta Milli Eğitim Bakanlığı olmak üzere birçok kurum ve kuruluşun problemli teknoloji kullanımı sorununun önlenmesine yönelik çalışmalar planlanması ve psikolojik danışmanların bu çalışmalarda etkin rol almaları problemli teknoloji kullanımı kavramının psikolojik danışmanlar arasında sıklıkla tartışılan bir konu haline gelmesine neden olmuştur.

$\mathrm{Bu}$ açıdan bakıldığında, bu araştırmada psikolojik danışma ve rehberlik alanında problemli teknoloji kullanımı üzerine yapılan lisansüstü tezlerin incelenmesi amaçlanmıştır. Önleyici ve koruyucu ruh sağlığı hizmetlerinin yürütülmesinde önemli bir konumda yer alan psikolojik danışmanların problemli teknoloji kullanımı üzerine hazırladıkları lisansüstü tezlerin incelenmesinin ve eğilimlerinin belirlenmesinin alanda 
çalışanlara ve araştırmacılara var olan bir durumu göstereceği düşünülmektedir.

\section{Araştırmanın Amacı}

Bu araştırmanın amacı, Türkiye' de psikolojik danışma ve rehberlik alanındaki problemli teknoloji kullanımı ile ilgili yapılmış lisansüstü tezleri inceleyerek alandaki araştırma eğilimlerinin belirlenmesidir. Araştırmanın bu genel amacı doğrultusunda aşağıdaki alt problemlere cevap aranmiştır:

Psikolojik Danışma ve Rehberlik alanındaki problemli teknoloji kullanımı üzerine yapılmış lisansüstü tezleri;

- Yilına,

- Tezin türüne,

- Üniversitenin türüne,

- Araştırma model çeşitliliğine,

- Çalışma grubu kimlerden oluştuğuna,

- Çalışma grubunun büyüklügüne,

- Kullanılan ölçme araçlarına,

- Yapilan istatistiksel analizlere,

- Problemli teknoloji kullanımı değişkenlerine,

- Problemli teknoloji kullanımı değişkeni ile birlikte çalışılan değişkenlere, göre nasıl bir dağılım göstermektedir?

\section{Yöntem}

Bu bölümde; araştırmanın modeli, çalışma grubu, veri toplama aracı ve işlem sürecine ilişkin bilgiler yer almaktadır.

\section{Araştırma Modeli}

$\mathrm{Bu}$ araştırma, ülkemizde psikolojik danışma ve rehberlik alanında problemli teknoloji kullanımı üzerine yapılan lisansüstü tezlerin eğilimlerini belirlemek amacıyla gerçekleştirilmiştir. Bu kapsamda verilerin analizi sürecinde içerik analizi yöntemi kullanılmıştır. İçerik analizi yöntemi; araştırılmak istenen durumlar veya olgular hakkındaki yazıll, görsel veya 
etkileşimli materyallerin belirli bir amaç doğrultusunda sistematik olarak incelenmesine dayanan bir yöntemdir (Büyüköztürk, Kılıç Çakmak, Akgün, Karadeniz ve Demirel, 2018; Silverman, 2015). İçerik analizi yöntemi, alandaki mevcut durumun ortaya koyulması, konu ile ilgili araştırma yapacak diğer araştırmacılara ve uygulama yapacak saha çalışanlarına yönelik kolaylık sağlaması açısından alanyazına önemli katkılar sunabilen bir yöntemdir (Drisko ve Maschi, 2015; Silverman, 2015). Bu kapsamda araştırmada, problemli teknoloji kullanımı ile ilgili lisansüstü tezler belirlenen çeşitli ölçütler çerçevesinde incelendiği için içerik analizi yöntemi kullanılmıştır.

\section{Analiz Kapsamında İncelenen Lisansüstü Tezler}

Araştırma kapsamında incelenecek lisansüstü tezler belirlenirken yapılandırılmış bir alanyazın taraması gerçekleştirilmiştir. Alanyazın taraması 2-30 Aralık 2020 tarihleri arasında YÖK Tez veri tabanında psikolojik danışma ve rehberlik alanında gerçekleştirilen lisansüstü tezlerini içerecek şekilde Türkçe olarak yapılmıştır. Problemli teknoloji kullanımı ile ilgili yapılan araştırmaları belirleyebilmek için alanyazın taramasında "internet bağımlılığı", "problemli internet kullanımı", "akıllı telefon bağımlılığı", "oyun bağımlılığı", "sosyal medya bağımlılı̆̆1", "nomofobi", "online alışveriş bağımlılı̆̆ı", "siberkondriya", "online pornografi bağımlılığı", "online kumar bağımlılı̆̆ı", "siber zorbalık" ve "siber mağduriyet" terimleri kullanılmıştır.

Alanyazın taraması sonucunda ulaşılan araştırmaların çalışma kapsamında alınmasında çeşitli dâhil edilme kriterleri göz önünde bulundurulmuştur. Araştırma kapsamına alınacak araştırmaların seçiminde kullanilan dâhil edilme kriterleri Tablo 1'de yer almaktadır.

Yapılan alanyazın taraması sonucunda toplam 679 lisansüstü teze ulaşılmış ve bunlar arasından dahil edilme kriterleri göz önünde bulundurularak 105 yüksek lisans tezi ve 10 doktora tezi olmak üzere toplamda 115 lisansüstü tezi araştırma kapsamında incelenmek üzere seçilmiştir. 
Tablo 1. Araştırma kapsamına alınacak araştırmaların seçiminde kullanılan dâhil edilme kriterleri

1 Psikolojik danışma ve rehberlik alanında; internet bağımlılığı, problemli internet kullanımı, akıllı telefon bağımlılığı, online oyun bağımlılığı, sosyal medya bağımlılığı, nomofobi, online alışveriş bağımlılı̆̆ı, siberkondriya, online pornografi bağımlılı̆̆ı, online kumar bağımlılığı, siber zorbalık ve siber mağduriyet değişkenleri ile yapılan lisansüstü tezler araştırma kapsamına alınmıştır.

2 Psikolojik danışma ve rehberlik, eğitimde psikolojik hizmetler, rehberlik ve psikolojik danışmanlık ile rehberlik ve psikolojik danışma lisansüstü programlarında tamamlanmış lisansüstü tezler araştırma kapsamına alınmıştır.

3 Araştırma Değerlendirme Formu kapsamında ele alınan kriterler hakkında bilgi verilen lisansüstü tezler araştırma kapsamına alınmıştır.

4 Tam metnine erişim izni olan lisansüstü tezleri araştırma kapsamına alınmıştır.

Araştırma kapsamında incelenen lisansüstü tezlerin yıllarına ve türlerine göre dağılımı Tablo 2' de gösterilmiştir.

Tablo 2. Araştırma kapsamında incelenen lisansüstü tezlerin yıllarına ve türlerine göre dă̆ılımı

\begin{tabular}{lllll}
\hline Yayın Yilı & Yüksek Lisans Tezi & Doktora Tezi & f & \% \\
\hline 2010 & 3 & - & 3 & 2.6 \\
2011 & 1 & - & 1 & 0.9 \\
2012 & 1 & - & 1 & 0.9 \\
2013 & 9 & 2 & 11 & 9.6 \\
2014 & 2 & - & 2 & 1.7 \\
2015 & 1 & 1 & 2 & 1.7 \\
2016 & 7 & - & 7 & 6.1 \\
2017 & 9 & 4 & 13 & 11.3 \\
2018 & 14 & - & 14 & 12.2 \\
2019 & 39 & 1 & 40 & 34.8 \\
2020 & 19 & 2 & 21 & 18.3 \\
\hline
\end{tabular}

\section{Veri Toplama Aracı}

Araştırma kapsamındaki lisansüstü tezlerin incelenmesi sürecinde araştırmacılar tarafından hazırlanan "Araştırma Değerlendirme Formu" (ADF) kullanılmıştır. Bu formun oluşturulmasındaki temel amaç, araştırma kapsaminda incelenecek lisansüstü tezlerin belirli bir sistematiğe göre incelenmesini gerçekleştirmektir. Buna bağlı olarak araştırmanın geçerliğinin ve güvenirliğinin artırılması amaçlanmıştır (Silverman, 2015). Bu formda; araştırma numarası, araştırma başlı̆̆ı, araştırmanın yılı, araştırmanın türü, üniversite türü, araştırma modeli, çalışma grubu, çalışma grubu büyüklügüu, kullanılan veri toplama aracı, yapılan analizler, problemli teknoloji kullanımı değişkeni ve diğer 
değişkenler olmak üzere 12 kategori bulunmaktadır. Oluşturulan bu forma problemli teknoloji kullanımı alanında araştırmalar yürüten 2 uzmandan görüş alınmıştır. Uzmanlardan alınan görüşler sonucunda problemli teknoloji kullanımı ile birlikte çalışılan diğer değişkenler kategorisi eklenmiştir. Ayrıca uzmanlar araştırma modeli ile ilgili sınıflandırmaya ilişkin çeşitli önerilerde bulunmuşlar ve bu kapsamda araştırmacılar tarafından düzenlemeler yapılarak veri toplama aşamasına geçilmiştir.

\section{Verilerin Analizi}

Araştırma kapsamında incelenecek lisansüstü tezler dahil edilme kriterleri göz önünde bulundurularak belirlendikten sonra içerik analizine tabi tutulmuştur. Büyüköztürk ve arkadaşları (2018) tarafından içerik analizinin aşamaları göz önünde bulundurularak verilerin analizi gerçekleştirilmiştir. Büyüköztürk ve arkadaşları (2018), içerik analizinin aşamalarını amaçları belirleme, kavramları tanımlama, analiz birimlerini belirleme, konu ile ilgili verilerin yerini belirleme, mantıksal bir yapıy geliştirme, kodlama kategorilerini belirleme, sayma, yorumlama ve sonuçları yazma aşamaları olarak sıralamaktadır. Verilerin analizi sürecinde araştırma kapsamında incelenecek 115 lisansüstü tez bilgisayar ortamına tam metinleri kaydedilerek ve ADF kullanılarak incelenmiştir. Bu sürecin daha sağlıklı ve hızlı bir şekilde gerçekleştirilebilmesi için ADF çevrimiçi bir veri toplama aracı olan Google Formlara aktarılmış ve veriler çevrimiçi ortamda elde edilmiştir. Daha sonrasında bütün veriler bilgisayar ortamına aktarılmıştır. Bilgisayar ortamına aktarılan verilerin Jamovi programı kullanılarak frekans ve yüzdeleri hesaplanmıştır. Ayrıca süreçte oluşturulan kodlamalara ilişkin uzman görüşü alınmıştır.

\section{Bulgular}

Araştırmanın bu bölümünde; araştırmanın genel ve alt amaçları doğrultusunda yapılan analizler sonucu ortaya çıan sonuçlar yer almaktadır. 
Yayın yılları: Türkiye'de psikolojik danışma ve rehberlik alanındaki lisansüstü tezlerde problemli teknoloji kullanımını ele alan lisansüstü tezler farklı yıllarda yayınlanmıştır. Bu lisansüstü tezlerin yayımlanma yıllarına ilişkin frekanslar Tablo 3'te gösterilmiştir.

Tablo 3. Lisansüstü tezlerin yayımlanma yıllarına ilişkin frekanslar

\begin{tabular}{lll}
\hline Y11 & f & \% \\
\hline 2010 & 3 & 2.6 \\
2011 & 1 & 0.9 \\
2012 & 1 & 0.9 \\
2013 & 11 & 9.6 \\
2014 & 2 & 1.7 \\
2015 & 2 & 1.7 \\
2016 & 7 & 6.1 \\
2017 & 13 & 11.3 \\
2018 & 14 & 12.2 \\
2019 & 40 & 34.8 \\
2020 & 21 & 18.3 \\
Toplam & $\mathbf{1 1 5}$ & $\mathbf{1 0 0}$ \\
\hline
\end{tabular}

Araştırma kapsamında incelenen lisansüstü tezlerin yayımlanma yılları incelendiğinde; 3 (\%2.6) araştırmanın 2010 yılında, 1'er (\%0.9) araştırmanın 2011 ve 2012 yıllarında, 11 (\%9.6) araştırmanın 2013 yılında, 2'şer (\%1.7) araştırmanın 2014 ve 2015 yıllarında, 7 (\%6.1) araştırmanın 2016 yılında, 13 (\%11.3) araştırmanın 2017 yılında, 14 (\%12.2) araştırmanın 2018 yılında, 40 (\%34.8) araştırmanın 2019 yılında ve 21 (\%18.3) araştırmanın 2020 yılında yayımlandığı görülmüştür. Bu bulguya göre psikolojik danışma ve rehberlik alanındaki problemli teknoloji kullanımı araştırmalarının 2015 yılı ile birlikte daha çok çalışılmaya başlandığı söylenebilir.

Lisansüstü Tez Türü: Türkiye'de psikolojik danışma ve rehberlik alanındaki lisansüstü tezlerde problemli teknoloji kullanımını ele alan lisansüstü tezler yüksek lisans ve doktora tezi olmak üzere 2 farklı şekilde ele alınabilmektedir. Bu lisansüstü tezlerin türlerine ilişkin frekanslar Tablo 4'te gösterilmiştir. 
Tablo 4. Lisansüstü tezlerin türlerine ilişkin frekanslar

\begin{tabular}{lll}
\hline Tez Türü & $\mathbf{f}$ & \% \\
\hline Yüksek Lisans Tezi & 105 & 91.3 \\
Doktora Tezi & 10 & 8.7 \\
Toplam & $\mathbf{1 1 5}$ & $\mathbf{1 0 0}$ \\
\hline
\end{tabular}

Araştırma kapsamında incelenen lisansüstü tezlerin türleri incelendiğinde; 105 (\%91.3) araştırmanın yüksek lisans tezi ve $10(\% 8.7)$ araştırmanın doktora tezi olduğu görülmüştür. Bu bulguya göre psikolojik danışma ve rehberlik alanındaki problemli teknoloji kullanımı araştırmalarının çoğunlukla yüksek lisans düzeyinde gerçekleştirildiği söylenebilir.

Üniversite türü: Türkiye'de psikolojik danışma ve rehberlik alanındaki lisansüstü tezlerde problemli teknoloji kullanımını ele alan lisansüstü tezler devlet ve vakıf olmak üzere 2 farklı türdeki üniversitelerde yayımlandığı görülmektedir. Bu lisansüstü tezlerin gerçekleştirildiği üniversite türlerine ilişkin frekanslar Tablo 5 'te gösterilmiştir.

Tablo 5. Lisansüstü tezlerin gerçekleştirildiği üniversite türlerine ilişkin frekanslar

\begin{tabular}{lll}
\hline Üniversite Türü & f & \% \\
\hline Devlet & 95 & 82.6 \\
Vakıf & 20 & 17.4 \\
Toplam & $\mathbf{1 1 5}$ & $\mathbf{1 0 0}$ \\
\hline
\end{tabular}

Araştırma kapsamında incelenen lisansüstü tezlerin gerçekleştirildiği üniversite türleri incelendiğinde; 95 (\%82.6) araştırmanın devlet üniversitelerinde ve 20 (\%17.4) araştırmanın vakıf üniversitelerinde gerçekleştirildiği görülmüştür. Bu bulguya göre psikolojik danışma ve rehberlik alanındaki problemli teknoloji kullanımı araştırmalarının çoğunlukla devlet üniversitelerindeki enstitülerde gerçekleştirildiği söylenebilir.

\section{Araştırma Modeli}

Türkiye' de psikolojik danışma ve rehberlik alanındaki lisansüstü tezlerde problemli teknoloji kullanımını ele alan lisansüstü tezler farklı araştırma 
modelleri ile gerçekleştirilmiştir. Bu lisansüstü tezlerin gerçekleştirildiği araştırma modellerine ilişkin frekanslar Tablo 6' da gösterilmiştir.

Tablo 6. Lisansüstü tezlerin araştırma modellerine ilişkin frekanslar

\begin{tabular}{lll}
\hline Araştırma Modelleri & $\mathbf{f}$ & $\mathbf{\%}$ \\
\hline Nicel Yöntem (Betimsel, İlişkisel, Nedensel vb.) & 106 & 92.2 \\
Nicel Yöntem (Deneysel) & 7 & 6.1 \\
Karma Yöntem (Açımlayıcı, Eş Zamanlı vb.) & 2 & 1.7 \\
Nitel Yöntem (Durum, Fenomenolojik vb.) & 0 & 0 \\
Toplam & $\mathbf{1 1 5}$ & $\mathbf{1 0 0}$ \\
\hline
\end{tabular}

Araştırma kapsamında incelenen lisansüstü tezlerin araştırma modelleri incelendiğinde; 106 (\%92.2) araştırmanın nicel yöntem (betimsel, ilişkisel, nedensel vb.), 7 (\%6.1) araştırmanın nicel yöntem (deneysel) ve 2 (\%1.7) araştırmanın karma yöntem (açımlayıcı, eş zamanlı vb.) ile gerçekleştirildiği görülmüştür. Bu lisansüstü tezlerin hiçbirisinde nitel yöntemin (durum, fenomenolojik vb.) kullanılmadığı görülmüştür. Bu bulguya göre psikolojik danışma ve rehberlik alanındaki problemli teknoloji kullanımı araştırmalarının çoğunlukla deneysel araştırma dışındaki nicel yöntemler ile gerçekleştirildiği söylenebilir.

\section{Çalışma Grupları}

Türkiye' de psikolojik danışma ve rehberlik alanındaki lisansüstü tezlerde problemli teknoloji kullanımını ele alan lisansüstü tezler farklı yaş gruplarındaki çalışma grupları ile gerçekleştirilmiştir. Bu lisansüstü tezlerin gerçekleştirildiği çalışma gruplarına ilişkin frekanslar Tablo 7'de gösterilmiştir.

Tablo 7. Lisansüstü tezlerin çalışma gruplarna ilişkin frekanslar

\begin{tabular}{lll}
\hline Araştırma Modelleri & f & \% \\
\hline İlkokul Öğrencileri & 2 & 1.7 \\
Ortaokul Öğrencileri & 16 & 13.3 \\
Lise Öğrencileri & 64 & 53.3 \\
Üniversite Öğrencileri & 33 & 27.5 \\
Yetişkinler & 5 & 4.2 \\
Toplam & $\mathbf{1 2 0}$ & $\mathbf{1 0 0}$ \\
\hline
\end{tabular}

Araştırma kapsamında incelenen lisansüstü tezlerin çalışma grupları incelendiğinde; 2 (\%1.7) araştırmanın ilkokul öğrencileri, 16 (\%13.3) 
araştırmanın ortaokul öğrencileri, 64 (\%53.3) araştırmanın lise öğrencileri, 33 (\%27.5) ve 5 (\%4.2) araştırmanın yetişkinler ile gerçekleştirildiği görülmüştür. Bu bulguya göre psikolojik danışma ve rehberlik alanındaki problemli teknoloji kullanımı araştırmalarının çoğunlukla lise ve üniversite öğrencileri ile gerçekleştirildiği söylenebilir.

\section{Çalışma Grubu Genişliği}

Türkiye'de psikolojik danışma ve rehberlik alanındaki lisansüstü tezlerde problemli teknoloji kullanımını ele alan lisansüstü tezler farklı çalışma grubu genişliği ile gerçekleştirilmiştir. Bu lisansüstü tezlerin çalışma grubu genişliğine ilişkin frekanslar Tablo 8' de gösterilmiştir.

Tablo 8. Lisansüstü tezlerin çalışma grubu genişliğine ilişkin frekanslar

\begin{tabular}{lll}
\hline Araştırma Modelleri & f & \% \\
\hline $1-100$ & 5 & 4.3 \\
$101-200$ & 4 & 3.5 \\
$201-400$ & 25 & 21.7 \\
$401-600$ & 38 & 33.0 \\
$601-800$ & 24 & 20.9 \\
$801-1000$ & 7 & 6.1 \\
1001 ve üzeri & 12 & 10.4 \\
Toplam & $\mathbf{1 1 5}$ & $\mathbf{1 0 0}$ \\
\hline
\end{tabular}

Araştırma kapsamında incelenen lisansüstü tezlerin çalışma grubu genişliği incelendiğinde; 5 (\%4.3) araştırmanın 1-100 kişi ile 4 (\%3.5) araştırmanın 101-200 kişi ile 25 (\%21.7) araştırmanın 201-400 kişi ile 38 (\%33.0) araştırmanın 401-600 kişi ile 24 (\%20.9) araştırmanın 601-800 kişi ile 7 (\%6.1) araştırmanın 801-1000 kişi ile ve 12 (\%10.4) araştırmanın 1001 ve üzeri kişi ile gerçekleştirildiği görülmüştür. Bu bulguya göre psikolojik danışma ve rehberlik alanındaki problemli teknoloji kullanımı araştırmalarının çoğunlukla 401-600 arasındaki kişi ile gerçekleştirildiği söylenebilir.

\section{Kullanılan Ölçme Araçları}

Türkiye'de psikolojik danışma ve rehberlik alanındaki lisansüstü tezlerde problemli teknoloji kullanımını ele alan lisansüstü tezlerde problemli teknoloji kullanımı değişkenini ölçmek için farklı ölçme araçları 
kullanılmıştır. Bu lisansüstü tezlerde kullanılan ölçme araçlarına ilişkin frekanslar Tablo 9'da gösterilmiştir.

Tablo 9. Lisansïstü tezlerde kullanılan problemli teknoloji kullanımı ölçme araçlarnna ilişkin frekanslar

\begin{tabular}{|c|c|c|}
\hline Ölçme Aracı & f & $\%$ \\
\hline İnternet Bağımlılığı Ölçeği - (Bayraktar, 2001) & 13 & 10.8 \\
\hline Problemli İnternet Kullanımı Ölçeği / Ergen Formu - (Ceyhan ve Ceyhan, 2009) & 11 & 9.2 \\
\hline Problemli İnternet Kullanımı Ölçeği - (Ceyhan, Ceyhan ve Gürcan, 2007) & 11 & 9.2 \\
\hline Young İnternet Bağımlılığı Testi / Kısa Form - (Kutlu, Savc1, Demir ve Aysan, 2016) & 8 & 6.7 \\
\hline \multicolumn{3}{|l|}{ Nomofobi Ölçeği - (Yildirim, Sumuer, Adnan ve Yildirim, 2016) } \\
\hline İnternet Bağımlılığı Ölçeği - (Günüç, 2009) & 7 & 5.8 \\
\hline Siber Zorbalık Ölçeği - (Arıcak, Tanrıkulu ve Kınay, 2012a) & 5 & 4.2 \\
\hline Akıllı Telefon Bağımlılı̆̆ı Ölçeği - (Akın, Altundağ, Turan ve Akın, 2014) & 5 & 4.2 \\
\hline Çocuklar İçin Bilgisayar Oyun Bağımlılığı Ölçeği - (Horzum, Ayas ve Çakır-Balta 2008) & 4 & 3.3 \\
\hline İnternette Bilişsel Durum Ölçeği - (Keser Özcan ve Buzlu, 2005) & 4 & 3.3 \\
\hline \multicolumn{3}{|l|}{ Akıllı Telefon Bağımlılığı Ölçeği - (Demirci, Orhan, Demirdas, Akpinar ve Sert, 2014) } \\
\hline Siber Mağduriyet ve Zorbalık Ölçeği - (Çetin, Yaman ve Peker, 2011) & 3 & 2.5 \\
\hline Yenilenmiş Siber Zorbalık Envanteri - (Topcu ve Erdur-Baker, 2010) & 3 & 2.5 \\
\hline \multicolumn{3}{|l|}{ Siber Mağduriyet Ölçeği - (Arıcak, Tanrıkulu ve Kınay, 2012b) } \\
\hline İnternet Bağımlılığı Testi - (Boysan ve arkadaşları, 2017) & 3 & 2.5 \\
\hline Sosyal Medya Bağımlılı̆̆ı Ölçeği - (Tutgun-Ünal, 2015) & 3 & 2.5 \\
\hline Sanal Zorba/Kurban Ölçeği - (Ayas ve Horzum, 2010) & 3 & 2.5 \\
\hline Akıllı Telefon Bağımlılı̆ı Ölçeği - (Şar, Ayas ve Horzum, 2015) & 2 & 1.7 \\
\hline Sosyal Medya Bağımlılığı / Yetişkin Formu - (Şahin ve Yağcı, 2017) & 2 & 1.7 \\
\hline \multirow[t]{4}{*}{ Diğer } & 2 & 1.7 \\
\hline & 2 & 1.7 \\
\hline & 2 & 1.7 \\
\hline & 27 & 22.5 \\
\hline Toplam & 120 & 100 \\
\hline
\end{tabular}

Araştırma kapsamında incelenen lisansüstü tezlerde kullanılan problemli teknoloji kullanımı ölçme araçları incelendiğinde; 13 (\%10.8) araştırmada İnternet Bağımlılı̆̆ Ölçeği - Bayraktar (2001), 11'er (\%9.2) araştırmada Problemli İnternet Kullanımı Ölçeği / Ergen Formu - Ceyhan ve Ceyhan (2009) ve Problemli İnternet Kullanımı Ölçeği - Ceyhan, Ceyhan ve Gürcan (2007), 8 (\%6.7) araştırmada Young İnternet Bağımlılığı Testi / Kisa Form - Kutlu ve arkadaşları (2016), 7 (\%5.8) araştırmada Nomofobi Ölçeği - Yıldırım ve arkadaşları (2016), 5'er (\%4.2) araştırmada İnternet Bağımlılığı Ölçeği - Günüç (2009) ve Siber Zorbalık Ölçeği - Arıcak, Tanrıkulu ve Kınay (2012), 4'er (\%3.3) araştırmada Akıllı Telefon Bağımlılığı Ölçeği - Akın ve arkadaşları (2014) ve Çocuklar İçin Bilgisayar Oyun Bağımlılığı Ölçeği - Horzum, Ayas ve Balta (2006), 3’er (\%2.5) araştırmada İnternette Bilişsel Durum Ölçeği - Özcan ve Buzlu (2005), Akıllı Telefon Bağımlılığı Ölçeği - Demirci ve arkadaşları (2014), Siber 
Mağduriyet ve Zorbalık Ölçeği - Çetin, Yaman ve Peker (2011), Yenilenmiş Siber Zorbalık Envanteri - Topçu ve Erdur-Baker (2010) ve Siber Mağduriyet Ölçeği - Arıcak, Tanrıkulu ve Kınay (2012), 2'şer (\%1.7) araştırmada İnternet Bağımlılı̆̆ Testi - Boysan ve arkadaşları (2017), Sosyal Medya Bağımlılığı Ölçeği - Tutgun-Ünal (2015), Sanal Zorba/Kurban Ölçeği - Ayas ve Horzum (2010), Akıllı Telefon Bağımlılı̆̆1 Ölçeği - Şar, Ayas ve Horzum (2015) ve Sosyal Medya Bağımlılı̆̆ 1 Yetişkin Formu - Şahin ve Yağcı (2017) kullanıldığ1 görülmüştür. Bu ölçme araçlarına ek olarak araştırmalarda 27 tane farklı ölçme aracı daha katılımcların problemli teknoloji kullanımı düzeylerini belirlemek için kullanılmıştır. Bu bulguya göre psikolojik danışma ve rehberlik alanındaki problemli teknoloji kullanımı araştırmalarında çoğunlukla İnternet Bağımlılığı Ölçeği - Bayraktar (2001), Problemli İnternet Kullanımı Ölçeği / Ergen Formu - Ceyhan ve Ceyhan (2009) ve Problemli İnternet Kullanımı Ölçeği - Ceyhan, Ceyhan ve Gürcan (2007) ölçme araçları kullanıldığı söylenebilir.

\section{Yapılan Analizler}

Türkiye'de psikolojik danışma ve rehberlik alanındaki lisansüstü tezlerde problemli teknoloji kullanımını ele alan lisansüstü tezlerde farklı analizler gerçekleştirilmiştir. Bu lisansüstü tezlerin çalışma grubu genişliğine ilişkin frekanslar Tablo 10'da gösterilmiştir.

Tablo 10. Lisansüstü tezlerde yapılan analizlere ilişkin frekanslar

\begin{tabular}{lll}
\hline Araştırma Modelleri & $\mathbf{f}$ & \% \\
\hline Korelasyon Analizi & 95 & 25.9 \\
ANOVA testi & 79 & 21.5 \\
t-testi & 78 & 21.3 \\
Regresyon Analizi & 61 & 16.6 \\
Kruskal Wallis H Testi & 18 & 4.9 \\
Mann-Whitney U-Testi & 16 & 4.3 \\
Doğrulayıcı Faktör Analizi & 5 & 1.3 \\
İçerik Analizi & 5 & 1.3 \\
Yapısal Eşitlik Modellemesi & 2 & 0.5 \\
MANOVA & 2 & 0.5 \\
Wilcoxon İşaretli Sıralar Testi & 2 & 0.5 \\
Ki Kare & 1 & 0.2 \\
ANCOVA & 1 & 0.2 \\
Betimsel Analiz & 1 & 0.2 \\
Toplam & 366 & $\mathbf{1 0 0}$ \\
\hline
\end{tabular}


Araştırma kapsamında incelenen lisansüstü tezlerde yapılan analizler incelendiğinde; 95 (\%25.9) araştırmada korelasyon analizi, 79 (\%21.5) araştırmada ANOVA testi, 78 (\%21.3) araştırmada t-testi, 61 (\%16.6) araştırmada regresyon analizi, 18 (\%4.9) araştırmada Kruskal Wallis H testi, 16 (\%4.3) araştırmada Mann-Whitney U-Testi, 5'er (\%1.3) araştırmada doğrulayıcı faktör analizi ve içerik analizi, 2'şer (\%0.5) araştırmada yapısal eşitlik modellemesi, MANOVA, Wilcoxon işaretli sıralar testi, 1'er $(\% 0.2)$ araştırmada ki kare, ANCOVA ve betimsel analiz kullanıldığı görülmüştür. Bu bulguya göre psikolojik danışma ve rehberlik alanındaki problemli teknoloji kullanımı araştırmalarında çoğunlukla korelasyon ve farklılaşma testlerinin kullanıldığı söylenebilir.

\section{Problemli Teknoloji Kullanımı Değişkenleri}

Türkiye' de psikolojik danışma ve rehberlik alanındaki lisansüstü tezlerde problemli teknoloji kullanımı ile ilgili farklı değişkenler özelinde çalışılmıştır. Bu lisansüstü tezlerde problemli teknoloji kullanımı değişkenlerine frekanslar Tablo 11'de gösterilmiştir.

Tablo 11. Lisansüstü tezlerde problemli teknoloji kullanımı değişkenlerine ilişkin frekanslar

\begin{tabular}{lll}
\hline PTK Değişkeni & f & \% \\
\hline İnternet Bağımlı̆ı̆ı & 34 & 28.09 \\
Problemli İnternet Kullanımı & 25 & 20.66 \\
Siber Zorbalık/Siber Mağduriyet & 19 & 15.70 \\
Çevrimiçi Oyun Bağımlılı̆ı & 15 & 12.39 \\
Akıllı Telefon Bağımlılığı & 12 & 9.91 \\
Nomofobi & 8 & 6.61 \\
Sosyal Medya Bağımlılığı & 8 & 6.61 \\
Toplam & $\mathbf{1 2 1}$ & $\mathbf{1 0 0}$ \\
\hline
\end{tabular}

Araştırma kapsamında incelenen lisansüstü tezlerde problemli teknoloji değişkenleri incelendiğinde; 34 (\%28.09) araştırmada internet bağımlılı̆̆ değişkeni, 25 (\%20.66) araştırmada problemli internet kullanımı değişkeni, 19 (\%15.70) araştırmada siber zorbalık/siber mağduriyet değişkeni, 15 (\%12.39) araştırmada çevrimiçi oyun bağımlılı̆̆1 değişkeni, 12 (\%9.91) araştırmada akıllı telefon bağımlılığı değişkeni, 8'er (\%6.61) araştırmada nomofobi ve sosyal medya bağımlılı̆̆ı değişkenleri ele alınmıştır. Bu bulguya göre psikolojik danışma ve rehberlik alanındaki 
problemli teknoloji kullanımı araştırmalarında çoğunlukla internet bağımlılı̆̆ ve problemli internet kullanımı değişkenleri ile gerçekleştirildiği söylenebilir.

\section{Problemli teknoloji kullanımı araştırmalarında çalışılan değişkenler}

Türkiye'de psikolojik danışma ve rehberlik alanındaki lisansüstü tezlerde problemli teknoloji kullanımını ele alan lisansüstü tezlerde farklı değişkenler çalışılmıştır. Bu lisansüstü tezlerde problemli teknoloji kullanımı ile çalışılan değişkenlere ilişkin frekanslar Tablo 12'de gösterilmiştir.

Araştırma kapsamında incelenen lisansüstü tezlerde problemli teknoloji kullanımı ile çalışılan değişkenler incelendiğinde; 89 (\%29) araştırmada sosyo-demografik değişkenlerin, 11 araştırmada yalnızlık değişkeninin, 10 araştırmada algılanan sosyal destek değişkeninin, 7'şer araştırmada depresyon, ebeveyn tutumları ve bağlanma stilleri değişkenlerinin, 6 'şar araştırmada kişilik özellikleri ve psikolojik iyi oluş değişkenlerinin, 5'er kez yaşam doyumu, temel psikolojik ihtiyaçlar ve öznel iyi oluş değişkenlerinin, 4'er kez mutluluk, iletişim becerileri, benlik saygısı, akran ilişkileri ve akademik erteleme değişkenlerinin, 3'er kez sosyal kaygı, duygu düzenleme, bilinçli farkındalık, psikolojik sağlamlık ve empatik eğilim değişkenlerinin ve 2'şer kez sosyal dışlanma, sosyal beceri, sosyal bağlılık, saldırganlık, psikolojik ihtiyaçların doyumu, problem çözme becerileri, okula bağlanma, evlilik uyumu, duygusal özerklik, bilişsel çarpıtmalar, aleksitimi, akademik güdülenme, öz-düzenleme, öfke ifade tarzı, koşullu öz-değer, beden algısı ve başa çıkma stratejileri değişkenleri incelenmiştir. Bu bulguya göre psikolojik danışma ve rehberlik alanındaki problemli teknoloji kullanımı araştırmalarında problemli teknoloji kullanımı ile çoğunlukla sosyo-demografik durum, yalnızlık, algılanan sosyal destek, depresyon, ebeveyn tutumları, bağlanma stilleri, kişilik özellikleri, psikolojik iyi oluş, yaşam doyumu, temel psikolojik ihtiyaçlar ve öznel iyi oluş değişkenleri ile çalışıldığı söylenebilir. 
Tablo 12. Lisansüstü tezlerde problemli teknoloji kullanımı ile çalışılan değişkenlere ilişkin frekanslar

\begin{tabular}{|c|c|c|c|c|c|}
\hline Değişken & $\mathrm{f}$ & $\%$ & Değişken & $\mathrm{f}$ & $\%$ \\
\hline Sosyo-Demografik Durum & 89 & 29 & Düşünce Baskılama & 1 & 0,3 \\
\hline Yalnızlık & 11 & 4 & Düşünme İhtiyacı & 1 & 0,3 \\
\hline Algilanan Sosyal Destek & 10 & 3 & Ebeveyn Algisı & 1 & 0,3 \\
\hline Depresyon & 7 & 2 & Ebeveyn Kabul-Red Algisı & 1 & 0,3 \\
\hline Ebeveyn Tutumları & 7 & 2 & Ebeveyn Reddi & 1 & 0,3 \\
\hline Bağlanma Stilleri & 7 & 2 & Ebeveyne Bağlanma & 1 & 0,3 \\
\hline Kişilik Özellikleri & 6 & 2 & Ebeveyn-Ergen İlişki Niteliği & 1 & 0,3 \\
\hline Psikolojik İyi Oluş & 6 & 2 & $\begin{array}{l}\text { Ebeveynlerin Problemli Davranışlar ile Başa Çıkma } \\
\text { Durumları }\end{array}$ & 1 & 0,3 \\
\hline Yaşam Doyumu & 5 & 2 & Endişe & 1 & 0,3 \\
\hline Temel Psikolojik İhtiyaçlar & 5 & 2 & Eş Seçme Kriterleri & 1 & 0,3 \\
\hline Öznel İyi Oluş & 5 & 2 & Eş Tükenmişliği & 1 & 0,3 \\
\hline Akademik Erteleme & 4 & 1 & Evliliğe Yüklenen Anlam & 1 & 0,3 \\
\hline Akran İlişkileri & 4 & 1 & Evlilik Doyumu & 1 & 0,3 \\
\hline Benlik Saygisı & 4 & 1 & Eylemli Kişilik & 1 & 0,3 \\
\hline İletişim Becerileri & 4 & 1 & Gelişmeleri Kaçırma Korkusu & 1 & 0,3 \\
\hline Mutluluk & 4 & 1 & Genel Aidiyet & 1 & 0,3 \\
\hline Bilinçli Farkındalık & 3 & 1 & Güvengenlik & 1 & 0,3 \\
\hline Duygu Düzenleme & 3 & 1 & Heyecan Arama & 1 & 0,3 \\
\hline Empatik Eğilim & 3 & 1 & İnsani Değerler & 1 & 0,3 \\
\hline Psikolojik Sağlamlık & 3 & 1 & İnternet Cazibesi & 1 & 0,3 \\
\hline Sosyal Kayg1 & 3 & 1 & İnternet Öz-yeterliliği & 1 & 0,3 \\
\hline Akademik Güdülenme & 2 & 1 & Karakter Güçleri & 1 & 0,3 \\
\hline Aleksitimi & 2 & 1 & Kendilik Alg1sı & 1 & 0,3 \\
\hline Başa Çıkma Stratejileri & 2 & 1 & Kendini Sansürleme & 1 & 0,3 \\
\hline Beden Algis1 & 2 & 1 & Narsistik Kişilik Eğilimi & 1 & 0,3 \\
\hline Bilişsel Çarpıtmalar & 2 & 1 & Olumsuz Ebeveyn Stilleri & 1 & 0,3 \\
\hline Duygusal Özerklik & 2 & 1 & Öğrenilmiş Güçlülük & 1 & 0,3 \\
\hline Evlilik Uyumu & 2 & 1 & Öz-duyarlık & 1 & 0,3 \\
\hline Koşullu Öz-Değer & 2 & 1 & Özgüven & 1 & 0,3 \\
\hline Okula Bağlanma & 2 & 1 & Öz-kontrol & 1 & 0,3 \\
\hline Öfke İfade Tarzı & 2 & 1 & Öznel İyi Oluşu Arttırma Stratejileri & 1 & 0,3 \\
\hline Öz-düzenleme & 2 & 1 & Öz-yeterlik & 1 & 0,3 \\
\hline Problem Çözme Becerileri & 2 & 1 & Psikolojik Belirtiler & 1 & 0,3 \\
\hline Psikolojik İhtiyaçların Doyumu & 2 & 1 & Psikolojik Durum & 1 & 0,3 \\
\hline Saldırganlık & 2 & 1 & Psikolojik Kontrol & 1 & 0,3 \\
\hline Sosyal Bağlılık & 2 & 1 & Red Duyarlılığg & 1 & 0,3 \\
\hline Sosyal Beceri & 2 & 1 & Riskli İnternet Davranışları & 1 & 0,3 \\
\hline Sosyal Dişlanma & 2 & 1 & Rüminasyon & 1 & 0,3 \\
\hline Aile İlişkileri & 1 & 0,3 & Sanal Ortamda Sosyal Etki & 1 & 0,3 \\
\hline Aile İşlevleri & 1 & 0,3 & Sinav Kaygisı & 1 & 0,3 \\
\hline Akademik Kendini Engelleme & 1 & 0,3 & Sosyal Görünüş Kaygısı & 1 & 0,3 \\
\hline Akılcı Olmayan İnançlar & 1 & 0,3 & Sosyal Medya Tutumları & 1 & 0,3 \\
\hline Akran Zorbalığ 1 & 1 & 0,3 & Sosyal Ortamlarda Gelişmeleri Kaçırma Korkusu & 1 & 0,3 \\
\hline Algılanan Duygusal İstismar & 1 & 0,3 & Sosyal Ortamlarda Yalnızlık & 1 & 0,3 \\
\hline Anksiyete & 1 & 0,3 & Sosyal Öz-Yeterlik & 1 & 0,3 \\
\hline Arkadaş Reddi & 1 & 0,3 & Sosyal Uyum & 1 & 0,3 \\
\hline Bilişsel Ayrışma & 1 & 0,3 & Sosyal Yabancılaşma & 1 & 0,3 \\
\hline Bilişsel Tamamlama & 1 & 0,3 & Sosyal Zekâ & 1 & 0,3 \\
\hline Çatışma Eğilimi & 1 & 0,3 & Stresle Başa Çıkma & 1 & 0,3 \\
\hline Davranış Problemleri & 1 & 0,3 & Suçluluk ve Utanç & 1 & 0,3 \\
\hline Davranışsal Kontrol & 1 & 0,3 & Sürekli Kayg1 & 1 & 0,3 \\
\hline Denetim Odağ1 & 1 & 0,3 & Sürekli Öfke & 1 & 0,3 \\
\hline Deneyimsel Kaçınma & 1 & 0,3 & Tepki Biçimleri & 1 & 0,3 \\
\hline Duyguları İfade Etme & 1 & 0,3 & Umutsuzluk & 1 & 0,3 \\
\hline Duygusal Şema & 1 & 0,3 & Utangançlık & 1 & 0,3 \\
\hline Duygusal Zekâ & 1 & 0,3 & Üstbiliş & 1 & 0,3 \\
\hline Dürtüsellik & 1 & 0,3 & Zorbalık Eğilimi & 1 & 0,3 \\
\hline
\end{tabular}




\section{Tartışma ve Sonuç}

Bireylerin teknolojiyi aşırı, kontrolsüz ve günlük yaşamlarına fiziksel, psikolojik ve sosyal olarak zarar verecek şekilde kullanımını ifade eden problemli teknoloji kullanımı son yıllarda sıklıkla karşılaşılan bir sorun haline gelmiştir (Lee ve Lee, 2017). Bu araştırmada, Türkiye'de psikolojik danışma ve rehberlik alanındaki problemli teknoloji kullanımı ile ilgili yapılmış lisansüstü tezlerin incelenmesi amaçlanarak bu alandaki çalışmaların genel çerçeveleri betimlenmiştir. İçerik analizi yöntemiyle gerçekleştirilen bu araştırmada 105'i yüksek lisans tezi ve 10'u doktora tezi olmak üzere 115 lisansüstü tezi; yayınlanma yılı, tez türü, üniversite türü, araştırma modeli, çalışma grubu, çalışma grubu genişliği, kullanılan ölçme aracı, yapılan istatistiksel analizler, problemli teknoloji kullanımı değişkeni ve problemli teknoloji kullanımı değişkeni ile çalışılan diğer değişkenler ölçütleri çerçevesinde incelenmiştir.

Araştırma kapsamında incelenen lisansüstü tezlerin büyük bir çoğunluğunun 2015 yılından sonra yapıldığı görülmüştür. Bu kapsamda araştırma bağlamında incelenen 115 lisansüstü tezin 95'inin 2015 yılından sonra yapıldığ 1 araştırma sonucunda elde edilmiştir. Bu bulguya benzer bir bulgu Boyacı (2019) tarafından Türkiye' de internet bağımlılığı üzerine yapılan araştırmaların incelendiği bir içerik analizi araştırmasında rastlanmıştır. Araştırmada, internet bağımlılığı üzerine yapılan araştırmaların 2015 yılıyla birlikte daha çok çalışıldığı görülmüştür. Problemli teknoloji kullanımı ile ilgili kavramların son yıllarda araştırma sahasında popüler olması ve bu sorunun son dönemlerde yaygınlaşması araştırma kapsamında incelenen lisansüstü tezlerin son 5 yılda yoğunlaşmasına neden olabildiği söylenebilir. Araştırmanın bir diğer bulgusunda, araştırma kapsamında incelenen lisansüstü tezlerin çok yüksek bir çoğunluğunun yüksek lisans tezi olduğu ve yalnızca 10 tane tezin doktora seviyesinde hazırlandığı görülmüştür. Başka bir bulguda ise araştırma kapsamında incelenen lisansüstü tezlerin 95'inin (\%82.6) devlet üniversitelerine bağl1 enstitülerde gerçekleştirildiği 20'sinin (\%17.4) ise vakıf üniversitelerine bağlı enstitülerde gerçekleştirildiği söylenebilir. Bu bulgu, 
Türkiye'de psikolojik danışma ve rehberlik alanındaki lisansüstü programların daha çok devlet üniversitelerine bağlı enstitülerde olması ile açıklanabilir.

Araştırma sonucunda Türkiye'de psikolojik danışma ve rehberlik alanındaki lisansüstü tezlerin 106'sının (\%92.2) deneysel desen dışındaki nicel yöntemlerle gerçekleştirildiği görülmüştür. Buna ek olarak 7 (\%6.1) araştırmada deneysel desenin kullanıldığı nicel yöntemler kullanılırken 2 (\%1.7) araştırmada karma yöntem kullanılmıştır. Boyacı (2019) tarafından gerçekleştirilen içerik analizi çalışmasında da internet bağımlılığı üzerine yapılan çalışmaların daha çok deneysel desen dişındaki nicel yöntemlerle gerçekleştirildiği görülmüştür. Araştırma kapsamında 7 lisansüstü tezde problemli teknoloji kullanımını azaltmaya yönelik bir program hazırlandığ1 ve etkililiğinin incelendiği deneysel desen kullanıldığı görülmüştür. Özellikle psikolojik danışma ve rehberlik alanında yürütülecek önleyici ve koruyucu ruh sağlı̆̆1 hizmetlerinde psiko-eğitim çalışmalarının önemi düşünüldüğünde problemli teknoloji kullanımını önlemeye yönelik etkililiği kanıtlanmış psiko-eğitim programlarının önemli bir role sahip olduğu söylenebilir. Bu bağlamda ülkemizde problemli teknoloji kullanımını önlemeye yönelik programların geliştirildiği ve etkililiğinin incelendiği deneysel desendeki araştırmaların artarak devam etmesinin önemli olabileceği söylenebilir. Araştırma kapsamında incelenen lisansüstü tezlerin çok küçük bir bölümünün karma yöntem ile gerçekleştirilmesi ve hiçbir lisansüstü tezde nitel araştırma yönteminin kullanılmaması bir eksiklik olarak ele alınabilmektedir. Nitel araştırmalar; bireylerin belirli bir durum, fenomen veya olguya ilişkin düşüncelerinin, duygularının ve davranışlarının derinlemesine inceleyen bir araştırma yöntemi (Büyüköztürk vd., 2018; Creswell, 2020; Yıldırım ve Şimşek, 2008) olması sebebiyle problemli teknoloji kullanımı araştırmalarında kullanılması literatüre ve sahaya büyük katkılar sunabileceği düşünülmektedir. Bu bağlamda problemli teknoloji kullanımı üzerine yürütülecek ilerleyen araştırmalarda nitel araştırma yönteminin kullanılmasının önemli olabileceği söylenebilir.

Araştırma kapsamında incelenen lisansüstü tezlerin çalışma grupları ölçütü açısından incelendiğinde, lisansüstü tezlerin 64'ünün (\%53.3) lise öğrencileri ile 33'ünün (\%27.5) üniversite öğrencileri ile 16’sının (\%13.3) ortaokul öğrencileri ile yürütüldüğü görülmüştür. Benzer bulguya Boyac1 
(2019) tarafından yapılan araştırmada da rastlanılmıştır. İlkokul öğrencileri ve yetişkinlerle yürütülen lisansüstü tezlerin çok sınırlı olması ve okul öncesi dönemdeki çocuklarla yapılan çalışmaların olmaması büyük bir eksiklik olarak düşünülmektedir. Bu bulgu, araştırma kapsamında incelenen lisansüstü tezlerin büyük bir çoğunluğunun nicel araştırma yöntemi ile gerçekleştirilmesi ve ölçme araçlarının lise ve üniversite grubundaki öğrencilere rahatlıkla ulaşılarak uygulanabilmesi ile açılanabilir. Ayrıca ülkemizde problemli teknoloji kullanımını belirlemeye yönelik kullanılan ölçme araçlarının geçerlik ve güvenirlik çalışmalarının daha çok bu yaş gruplarında gerçekleştirilmesinin araştırma kapsamında incelenen lisansüstü tezlerin lise ve üniversite öğrencileri ile gerçekleştirilmesine neden olduğu söylenebilir (Kabadayı, 2020). Psikolojik danışma ve rehberlik hizmetlerinin tüm yaş gruplarındaki bireylere yönelik sunulan bir hizmet olması ve problemli teknoloji kullanımının okul öncesinden itibaren tüm yaş grupları açısından yaygın bir sorun olduğunun bilinmesi bakımından ilerleyen araştırmalarda göz ardı edilmiş çalışma gruplarına yönelik araştırmaların yürütülmesinin önemli olabileceği söylenebilir. Ayrıca alanyazında problemli teknoloji kullanımının yaygınlığı üzerine yapılan araştırmaların da daha çok lise ve üniversite öğrencileri ile yürütülmesi ve okul öncesi, ilkokul ve yetişkin grupları ile yürütülen çalışmaların çok sınırlı olması bu göz ardı edilen gruplarda problemli teknoloji kullanımının yaygınlığı konusundaki bilgilerin sınırlı olmasına neden olabilmektedir (Lee ve Lee, 2017; Li vd., 2018; Sert, Taskin Yilmaz, Karakoc Kumsar ve Aygin, 2019). Araştırma kapsamında elde edilen bir başka sonuç ise lisansüstü tezlerin çalışma gruplarının 200 ile 800 kişi arasında bir yığılma göstermesidir. Bu bulgu Boyacı (2019) tarafından yapılan bir araştırmadaki bulguyu desteklemektedir.

Araştırma kapsamında incelenen lisansüstü tezlerde problemli teknoloji kullanımı değişkenini ölçmek için 13 (\%10.8) araştırmada İnternet Bağımlılığı Ölçeği (Bayraktar, 2001), 11'er (\%9.2) araştırmada Problemli İnternet Kullanımı Ölçeği / Ergen Formu (Ceyhan ve Ceyhan, 2009) ve Problemli İnternet Kullanımı Ölçeği (Ceyhan, Ceyhan ve Gürcan, 2007), 8 (\%6.7) araştırmada Young İnternet Bağımlılığı Testi / Kısa Form (Kutlu vd., 2016) ve 7 (\%5.8) araştırmada Nomofobi Ölçeği (Yildirim vd., 2016) kullanıldığ1 görülmüştür. Lisansüstü tezlerde en çok kullanılan 5 ölçme aracının 4'ünün internet bağımlılığı ve problemli internet kullanımı 
ölçme araçları olduğu görülmüştür. Araştırma kapsamında incelenen lisansüstü tezlerin büyük bir çoğunluğunun internet bağımlılı̆̆ı ve problemli internet kullanımı üzerine yapıldığı için bu değişkenleri belirlemeye yönelik ölçme araçlarının daha fazla kullanıldığı söylenebilir. Ayrıca ülkemizde nomofobiyi ölçmeye yönelik ölçme araçlarının çok sınırlı olması nomofobi üzerine yapılan araştırmaların tümünde Yildirim ve arkadaşları (2016) tarafından uyarlanan ölçme aracının kullanılmasına neden olduğu söylenebilir. Araştırmada elde edilen bir başka sonuçta ise araştırmalarda en çok korelasyon analizi (\%25.9) kullanıldığı ve bu analizi ANOVA testi (\%21.5), t-testi (\%21.3), regresyon analizi (\%16.6) ve Kruskal Wallis $\mathrm{H}$ testi (\%4.9) takip ettiği görülmüştür. Araştırma kapsamında incelenen lisansüstü tezlerin çoğunlukla nicel yöntem ile gerçekleştirilmesi ve sosyo-demografik durum değişkeninin çok fazla kullanılması araştırmalarda ilişki, yordama ve farklılaşma testlerinin çok sık kullanılmasına yol açtığı söylenebilir.

Araştırma kapsamında incelenen lisansüstü tezlerin problemli teknoloji kullanımı değişkenleri açısından incelendiği; lisansüstü tezlerin 34'ünün (\%28.09) internet bağımlılığı, 25'inin (\%20.66) problemli internet kullanımı, 19'unun siber zorbalı/siber mağduriyet, 15'inin (\%12.39) çevrimiçi oyun bağımlılığı, 12'sinin (\%9.91) akıllı telefon bağımlılığı ve 8'inin (\%6.61) nomofobi ve sosyal medya bağımlılığı değişkenleri olduğu görülmüştür. Lisansüstü tezlerde problemli teknoloji kullanımı değişkenleri olarak online alışveriş bağımlılığı, siberkondriya, online pornografi bağımlılığı ve online kumar bağımlılığı gibi ele alınmaması bir sinırlılık olarak görülebilmektedir. Çünkü göz ardı edilen bu problemli teknoloji kullanımı değişkenleri de son yıllarda sıklıkla karşımıza çıkan ve üstünde çalışılması gereken değişkenlerdir (Savcı, Ercengiz ve Aysan, 2019). Bu bağlamda ilerleyen zamanlarda yürütülecek araştırmalarda bu değişkenlere yönelik çalışmaların yapılması büyük önem taşıyabileceği söylenebilir. Araştırmada son olarak lisansüstü tezlerde problemli teknoloji kullanımı ile birlikte çalışılan diğer değişkenler incelenmiştir. Lisansüstü tezlerde problemli teknoloji kullanımı ile birlikte çalışılan diğer değişkenlerin 89 araştırmada sosyo-demografik durum, 11 araştırmada yalnızlık, 10 araştırmada algilanan sosyal destek ve 7 'şer araştırmada depresyon, ebeveyn tutumları ve bağlanma stilleri olduğu, 6'şar araştırmada kişilik 
özellikleri ve psikolojik iyi oluş, 5'er araştırmada yaşam doyumu, temel psikolojik ihtiyaçlar ve öznel iyi oluş olduğu görülmüştür.

Bu araştırma, Türkiye'de psikolojik danışma ve rehberlik alanındaki problemli teknoloji kullanımı ile ilgili yapılmış lisansüstü tezlerin belirli kriterler çerçevesinde incelenmesine dayanan bir içerik analizi çalışmasıdır. Bu kapsamda araştırmada yalnızca Türkiye'de ve psikolojik danışma ve rehberlik alanında gerçekleştirilmiş lisansüstü tezler incelenmiştir. İlerleyen araştırmalarda daha geniş alanlarda ve ülkelerde yapılmış lisansüstü tezlerin ve diğer araştırmaların dahil edilerek çalışmaların yapılabileceği söylenebilir. Ayrıca araştırma kapsamında incelenen lisansüstü tezlerde göz ardı edilen alanlara yönelik çalışmalar yürütülmesi gerektiği söylenebilir. Sonuç olarak bu araştırma, Türkiye'de psikolojik danışma ve rehberlik alanındaki lisansüstü tezlerde problemli teknoloji kullanımına bir fotoğraf çekmesi bakımından önemli olduğu ve bu konu üzerinde çalışan araştırmacılar ile saha çalışanlarına bir kaynak sunabileceği düşünülmektedir. 


\title{
EXTENDED ABSTRACT
}

\section{Problematic Technology Use in Theses in Psychological Counseling and Guidance in Turkey}

\author{
Önder Baltacı- Ömer Faruk Akbulut \\ Ahi Evran University-Necmettin Erbakan University
}

Technology with many developments and innovations emerges as a tool encompassing all areas of our lives nowadays. In the report "Digital 2020" published by We Are Social (2020); it has been observed that $67 \%$ of the world population owns a telephone, $59 \%$ is internet users and $49 \%$ is active social media users. Individuals can fulfill their professional and academic responsibilities in their daily lives, many responsibilities at home, and activities in their social lives through technological tools. This convenience created by technology on individuals can be seen as an opportunity (Ögel, 2014). However, as a result of the uncontrolled, unconscious and problematic use of technology, the lives of individuals can be negatively affected by this situation (Spada, 2014). The use of technology by individuals in this way can be considered as "problematic technology use" in the literature. The concept of problematic technology use is a general concept in the literature that includes concepts such as problematic internet use, game addiction, problematic smartphone use, and internet addiction. In this context, problematic technology use can be defined as having difficulties in controlling the use of technology by individuals, keeping their minds constantly busy with technology when they cannot access technology, taking up an excessive amount of time in their daily life and these situations negatively affect the daily life of the individual (Block, 2008; Şata and Karip, 2017; Young, 2011). In this study, it is aimed to examine the graduate theses on problematic technology use in the field of psychological counseling and guidance. It is thought that examining graduate theses prepared by psychological counselors, who have an important role in the execution of preventive mental health services and determining their tendencies will show the current situation to the professionals and researchers in the field. 
Content analysis method was used in the process of data analysis in the research. Content analysis method is a method based on the systematic examination of written, visual or interactive materials about the situations or facts to be examined for a specific purpose (Büyüköztürk, Kılıç Çakmak, Akgün, Karadeniz and Demirel, 2018; Silverman, 2015). While determining the graduate theses to be examined within the scope of the research, a structured literature review was carried out. In order to determine the researches on problematic technology use, "internet addiction", "problematic internet use", "smartphone addiction", "game addiction", "social media addiction", "nomophobia", "online shopping addiction", " Cyberchondria", "online pornography addiction", "online gambling addiction", "cyber bullying" and "cyber victimization" terms were used. Various inclusion criteria were taken into consideration in the inclusion of the studies obtained as a result of the literature review. As a result of the literature review, a total of 679 graduate theses were reached, and considering the inclusion criteria, a total of 115 graduate theses, including 105 master's theses and 10 doctoral dissertations, were selected to be examined within the scope of the research. In the process of examining the graduate theses within the scope of the research, the "Research Evaluation Form" (REF) prepared by the researchers was used.

It was obtained that 95 of the 115 graduate theses examined in the context of the research were made after 2015. Concepts related to problematic use of technology have become popular in the research field in recent years and this problem has become widespread so it can be said that the graduate theses examined within the scope of the research intensify in the last 5 years. In another finding of the study, it was seen that the majority of the graduate theses examined within the scope of the research were master's theses and only 10 theses were prepared at the doctoral level. It can also be said that 95 of the graduate theses examined within the scope of the research were carried out in institutes affiliated to state universities, and 20 were carried out in foundation ones. This finding can be explained by the fact that graduate programs in the field of psychological counseling and guidance in Turkey are mostly in institutes affiliated with state universities. In addition, while quantitative methods using experimental design were used in 7 studies, mixed method was used in 2 studies. The fact that a very small part of the graduate theses examined within the scope of 
the research was carried out with the mixed method and the qualitative research method was not used in any graduate thesis can be considered as a deficiency. In this context, it can be said that it may be important to use qualitative research methods in future studies on problematic technology use. When the graduate theses examined within the scope of the research were examined in terms of the study groups' criteria, it was seen that 64 of the graduate theses were conducted with high school students, 33 with university students and 16 with middle school students. The very limited number of graduate theses conducted with primary school students and adults and the lack of studies with pre-school children is considered to be a major deficiency. This finding can be explained by the fact that most of the graduate theses examined within the scope of the research are carried out by quantitative research method and the assessment instruments can be easily reached and applied to students in high school and university groups. In addition, it can be said that the validity and reliability studies of the assessment instruments used to determine the use of problematic technology in our country are mostly carried out in these age groups, causing the graduate theses examined within the scope of the research to be carried out with high school and university students (Kabaday1, 2020). In order to assess the problematic technology use variable in graduate theses, "The Internet Addiction Scale (Bayraktar, 2001) in 13 studies, the Problematic Internet Use Scale / Adolescent Form (Ceyhan and Ceyhan, 2009) and the Problematic Internet Use Scale (Ceyhan, Ceyhan and Gürcan, 2007) in 11 studies, Young's Internet Addiction Test / Short Form (Kutlu et al., 2016) in 8 studies, and the Nomophobia Scale (Yildirim et al., 2016) in 7 studies" were used in the research. It was observed that 4 of the 5 most commonly used assessment instrument in graduate theses were internet addiction and problematic internet use. Since most of the graduate theses examined within the scope of the research are about internet addiction and problematic internet use, it can be said that assessment instruments are used more to determine these variables. According to another result of the study, it was seen that correlation analysis was mostly used in the studies and this analysis was followed by ANOVA test, t-test, regression analysis and Kruskal Wallis $\mathrm{H}$ test. It can be said that most of the graduate theses examined within the scope of the research are carried out by quan- 
titative method and the excessive use of the socio-demographic status variable causes the relationship, prediction and differentiation tests to be used very frequently in research. When these graduate theses were examined in terms of problematic technology usage variables it was observed that 34 of the graduate theses were internet addiction, 25 were problematic internet use, 19 were cyber bullying / cyber victimization, 15 were online game addiction, 12 were smartphone addiction, and 8 were nomophobia and social media addiction variables. In graduate theses, it can be seen as a limitation that problematic technology use variables are not addressed as online shopping addiction, cyberchondria, online pornography addiction and online gambling addiction. Because these problematic technology usage variables that have been overlooked are the variables that we have encountered frequently in recent years and need to be studied (Savc1, Ercengiz and Aysan, 2019). Finally, in the research, other variables worked with problematic technology use in graduate theses were examined. Other variables studied together with problematic technology use in graduate theses are socio-demographic status in 89 studies, loneliness in 11 studies, perceived social support in 10 studies, and depression, parental attitudes and attachment styles in 7 studies, personality traits and psychological well-being in 6 studies, life satisfaction, basic psychological needs and subjective well-being in 5 studies.

\section{Kaynakça / References}

Aboujaoude, E. (2010). Problematic Internet use: an overview. World Psychiatry, 9(2), 85-90. https://dx.doi.org/10.1002\%2Fj.2051-5545.2010.tb00278.x

Akın, A., Altundağ, Y., Turan, M. E. ve Akın, Ü. (2014). The validity and reliability of the Turkish version of the smart phone addiction scale-short form for adolescent. Procedia - Social and Behavioral Sciences, 152, 74-77. https://doi.org/10.1016/j.sbspro.2014.09.157

Arıcak, O. T., Kınay, H. ve Tanrıkulu, T. (2012). Siber zorbalık ölçeğinin ilk psikometrik bulguları. Hasan Ali Yücel Eğitim Fakültesi Dergisi, 17(1), 101114.

Arıcak, O., Tanrıkulu, T. ve Kınay, H. (2012). Siber mağduriyet ölçeğinin ilk psikometrik bulguları. Akdeniz Eğitim Araştırmaları Dergisi, 11, 1-6. 
Avşaroğlu, S. ve Akbulut, Ö. F. (2020). Sağlıklı aile yapısı açısından bir risk faktörü: İnternet bağımlılığı. International Social Sciences Studies Journal, 6(65), 2879-2902. http://dx.doi.org/10.26449/sssj.2456

Ayas, T. ve Horzum, M. B. (2010). Sanal zorba/kurban ölçek geliştirme çalışması. Akademik Bakış : Uluslararası Hakemli Sosyal Bilimler E-Dergisi, 19, 1-17.

Baranowski, T., Baranowski, J., Thompson, D., Buday, R., Jago, R., Griffith, M. J. and Watson, K. B. (2011). Video game play, child diet, and physical activity behavior change: A randomized clinical trial. American Journal of Preventive Medicine, 40(1), 33-38. https://doi.org/10.1016/j.amepre.2010.09.029

Bayraktar, F. (2001). Internet kullanımının ergen gelişimindeki rolü. Yüksek Lisans Tezi. Ege Üniversitesi, Sosyal Bilimler Enstitüsü, İzmir.

Block, J. J. (2008). Issues for DSM-V: Internet addiction. The American Journal of Psychiatry, 165, 306-307. https://doi.org/10.1176/appi.ajp.2007.07101556

Boyacı, M. (2019). Türkiye' de internet bağımlılığı araştırmaları: Bir içerik analizi çalışması. Addicta: The Turkish Journal on Addictions, 6, 777-795. https://doi.org/10.15805/addicta.2019.6.3.0030

Boysan, M., Kuss, D. J., Barut, Y., Ayköse, N., Güleç, M. ve Özdemir, O. (2017). Psychometric properties of the Turkish version of the Internet Addiction Test (IAT). Addictive Behaviors, 64, 247-252. https://doi.org/10.1016/j.addbeh.2015.09.002

Büyüköztürk, Ş., K1lıç Çakmak, E., Akgün, Ö. E., Karadeniz, Ş. ve Demirel, F. (2018). Ĕ̆itimde bilimsel araştırma yöntemleri. Ankara: Pegem.

Çetin, B., Yaman, E. ve Peker, A. (2011). Cyber victim and bullying scale: A study of validity and reliability. Computers and Education, 57(4), 22612271. https://doi.org/10.1016/j.compedu.2011.06.014

Ceyhan, A. A. ve Ceyhan, E. (2009). Ergenlerde problemli internet kullanım ölçeği (PÍKÖ-E) geliştirme çalışmaları. X. Ulusal Psikolojik Danışma ve Rehberlik Kongresi. Adana

Ceyhan, E., Ceyhan, A. A. ve Gürcan, A. (2007). Problemli internet kullanımı ölçeği'nin geçerlik ve güvenirlik çalışmaları. Kuram ve Uygulamada Eğitim Bilimleri (KUYEB) Dergisi, 7, 387-416.

Creswell, J. W. (2020). Nitel araştırma yöntemleri: Beş yaklaşıma göre nitel araştırma ve araştırma deseni. Ankara: Siyasal.

Demirci, K., Orhan, H., Demirdas, A., Akpinar, A. ve Sert, H. (2014). Validity and reliability of the Turkish Version of the Smartphone Addiction 
Scale in a younger population. Klinik Psikofarmakoloji Bülteni-Bulletin of Clinical Psychopharmacology, 24(3), 226-234. https://doi.org/10.5455/bcp.20140710040824

Drisko, J. W. and Maschi, T. (2015). Content analysis: Pocket guides to social work research method. Oxford University Press.

Erdur-Baker, Ö. ve Kavşut, F. (2007). Akran zorbalığının yeni yüzü: Siber zorbalık. Eurasian Journal of Educational Research (EJER), 27, 31-42.

Günüç, S. (2009). İnternet Bağımlılık Ölçeğinin geliştirilmesi ve bazı demografik değişkenler ile İnternet bağımlılı̆̆ı arasındaki ilişkilerin incelenmesi. Yüksek Lisans Tezi. Yüzüncü Yıl Üniversitesi, Sosyal Bilimler Enstitüsü, Van.

Horzum, M. B., Ayas, T. ve Çakır-Balta, Ö. (2008). Çocuklar için Bilgisayar Oyun Bağımlılığı Ölçeği. Türk Psikolojik Danışma ve Rehberlik Dergisi, 3(30), 7688.

Kabadayı, F. (2020). Psychometric properties of Turkish cyberpsychology scales. Turkish Psychological Counseling and Guidance Journal, 10(58), 385411.

Keser Özcan, N. ve Buzlu, S. (2005). Problemli internet kullanımını belirlemede yardımcı bir araç: "İnternette Bilişsel Durum Ölçeği"nin üniversite öğrencilerinde geçerlik ve güvenirliği. Bağımlılık Dergisi, 6(1), 19-26.

Kutlu, M., Savc1, M., Demir, Y. ve Aysan, F. (2016). Young İnternet Bağımlılığı Testi Kısa Formunun Türkçe uyarlaması: Üniversite öğrencileri ve ergenlerde geçerlilik ve güvenilirlik çalışması. Anadolu Psikiyatri Dergisi, 17(1), 69-76. https://doi.org/ 10.5455/apd.190501

Lee, C. and Lee, S.-J. (2017). Prevalence and predictors of smartphone addiction proneness among Korean adolescents. Children and Youth Services Review, 77, 10-17. https://doi.org/10.1016/j.childyouth.2017.04.002

Li, L., Xu, D. D., Chai, J. X., Wang, D., Li, L., Zhang, L. and Xiang, Y. T. (2018). Prevalence of Internet addiction disorder in Chinese university students: A comprehensive meta-analysis of observational studies. Journal of Behavioral Addictions, 7(3), 610-623. https://doi.org/10.1556/2006.7.2018.53

Ögel, K. (2014). İnternet bağımlılığı: İnternetin psikolojisini anlamak ve bağımlılıkla başa çıkmak. İstanbul: İş Bankası Kültür Yayınları.

Savcı, M., Ercengiz, M. ve Aysan, F. (2019). Problemli teknoloji kullanımı. Ankara: Pegem. https://doi.org/10.14527/9786052418659

Savi Çakar, F. (2018). Önleyici psikolojik danı̧ma kuram ve uygulamaları. Ankara: Pegem. 
Sert, H., Taskin Yilmaz, F., Karakoc Kumsar, A. ve Aygin, D. (2019). Effect of technology addiction on academic success and fatigue among Turkish university students. Fatigue: Biomedicine, Health \& Behavio, 7(1), 41-51. https://doi.org/10.1080/21641846.2019.1585598

Spada, M. M. (2014). An overview of problematic Internet use. Addictive Behaviors, 39(1), 3-6. https://doi.org/10.1016/j.addbeh.2013.09.007

Silverman, D. (2015). Interpreting qualitative data. Sage Publications.

Şahin, C. ve Yağcı, M. (2017). Sosyal Medya Bağımlılığı Ölçeği-Yetişkin Formu: Geçerlilik ve güvenirlik çalışması. Ahi Evran Üniversitesi Kırşehir Ĕ̆itim Fakültesi Dergisi (KEFAD), 14(1), 523-538.

Sakarya Üniversitesi, İHH, ve AID. (2015). Teknoloji kullanımı ve bağımlılı̆̆ açısından Türkiye gençliğinin fotoğrafi. 15/01/2021 tarihinde https://insamer.com/rsm/icerik/dosya/dosya_182.pdf adresinden alındı.

Şar, A. H., Ayas, T. ve Horzum, M. B. (2015). Akıllı telefon bağımlılığı ölçeği geliştirme; geçerlik ve güvenirlik çalışması. Online Journal Of Technology Addiction \& Cyberbullying, 2(1), 1-17.

Şata, M. ve Karip, F. (2017). Akıllı Telefon Bağımlılığı Ölçeği-Kısa Versiyonu'nun ergenler için Türk kültürüne uyarlanması. Cumhuriyet International Journal of Education, 6(4), 426-440.

Topcu, Ç. ve Erdur-Baker, Ö. (2010). The revised cyber bullying inventory (RCBI): Validity and reliability studies. Procedia-Social and Behavioral Sciences, 5, 660-664. https://doi.org/10.1016/j.sbspro.2010.07.161

Türkiye Yeşilay Cemiyeti. (2017). Teknoloji yerinde yeterince. 15/02/2021 tarihinde https://tbm.org.tr/media/kitaplar/TBM_yetiskin_teknoloji_icerik_web.pdf adresinden alınd.

Tutgun-Ünal, A. (2015). Sosyal medya bağımlılığı: Üniversite öğrencileri üzerine bir araştırma. Doktora Tezi. Marmara Üniversitesi, Sosyal Bilimler Enstitüsü, İstanbul.

Wang, Q., Liu, Y., Wang, B., An, Y., Wang, H., Zhang, Y. and Mati, K. (2020). Problematic internet use and subjective sleep quality among college students in China: Results from a pilot study. Journal of American College Health, 1-9. https://doi.org/10.1080/07448481.2020.1756831

We Are Social. (2020). Digital 2020. 15/02/2021 tarihinde https://wearesocial.com/blog/2020/01/digital-2020-3-8-billion-people-use-social-media\#: :text=More than 4.5 billion people,the middle of this year. adresinden alındı. 
Wittek, C. T., Finserås, T. R., Pallesen, S., Mentzoni, R. A., Hanss, D., Griffiths, M. D. and Molde, H. (2016). Prevalence and predictors of video game addiction: A study based on a national representative sample of gamers. International Journal of Mental Health and Addiction, 14(5), 672-686. https://doi.org/10.1007/s11469-015-9592-8

Yeşilyaprak, B. (2020). 21.yüzyılda eğitimde rehberlik hizmetleri. Ankara: Nobel.

Yildirim, C. ve Correia, A. P. (2015). Exploring the dimensions of nomophobia: Development and validation of a self-reported questionnaire. Computers in Human Behavior, 49, 130-137. https://doi.org/10.1016/j.chb.2015.02.059

Yildirim, C., Sumuer, E., Adnan, M. ve Yildirim, S. (2016). A growing fear: Prevalence of nomophobia among Turkish college students. Information Development, 32(5), 1322-1331. https://doi.org/10.1177/0266666915599025

Yıldırım, A. ve Şimşek, H. (2008). Sosyal bilimlerde nitel araştırma yöntemleri. Ankara: Seçkin.

Young, K. S. (2011). CBT-IA: The first treatment model for internet addiction. Journal of Cognitive Psychotherapy, 25(4), 304-312. https://doi.org/ 10.1891/0889-8391.25.4.304

Zheng, Y., Wei, D., Li, J., Zhu, T. and Ning, H. (2016). Internet use and its impact on individual physical health. IEEE Access, 4, 5135-5142. https://doi.org/10.1109/ACCESS.2016.2602301

\section{Kaynakça Bilgisi / Citation Information}

Baltacı, Ö. ve Akbulut, Ö. F. (2021). Türkiye'de Psikolojik Danışma ve Rehberlik alanındaki tezlerde problemli teknoloji kullanımı. OPUSUluslararası Toplum Araştırmaları Dergisi, 18(Eğitim Bilimleri Özel Say1s1), 4952-4982. DOI: 10.26466/opus.906742. 